\title{
Legal Scholarship and Digital Publishing: Has Anything Changed in the Way We Do Legal Research?
}

\author{
E. Dana Neacsu
}

\begin{abstract}
SUMMARY. Scholarship, including legal scholarship, depends on the reliability of sources used so that subsequent scholars can build upon the work. Reliability is here defined as including accurate access to sources that reproduce faithfully the original source. Legal scholarship depends on the existence and reliability of accessible materials to verify the accuracy and validity of the ideas advanced in the source. The growth of digital publishing, ${ }^{1}$ which includes both distributing information directly in electronic format and the conversion of paper materials into electronic format, threatens the established reliability of source materials. The current legal literature has failed to address this issue; the author's examination of 20 law review articles, all containing at least four citations to the Internet, found that 12 of the 20 contained an online source which could
\end{abstract}

E. Dana Neacsu (Facultatea de Drept, Bucharest, Diploma de Drept, Faculte de Droit et des Etudes Politiques, Caen, France, DEA, Harvard Law School, LLM, and CUNY, MLS) is Reference Librarian, Arthur W. Diamond Law Library, Columbia Law School and a New York attorney.

The author would like to thank CUNY Professor Colleen Cool, Jody Armstrong, and Kent McKeever for their invaluable assistance.

This article was first presented as a paper at the conference, "Not a Box but a Window: Law Libraries and Legal Education in a Virtual World," held at Bora Laskin Law Library, Faculty of Law, University of Toronto, on Feb. 22-24, 2001. A draft of the oral presentation can be viewed at <http://www.law-lib.utoronto.ca/conferences/future/archives.htm>.

[Haworth co-indexing entry note]: "Legal Scholarship and Digital Publishing: Has Anything Changed in the Way We Do Legal Research?" Neacsu, E. Dana. Co-published simultaneously in Legal Reference Services Quarterly (The Haworth Information Press, an imprint of The Haworth Press, Inc.) Vol. 21, No. 2/3, 2002, pp. 105-122; and: Law Library Collection Development in the Digital Age (ed: Michael Chiorazzi, and Gordon Russell) The Haworth Information Press, an imprint of The Haworth Press, Inc., 2002, pp. 105-122. Single or multiple copies of this article are available for a fee from The Haworth Document Delivery Service [1-800-HAWORTH, 9:00 a.m. - 5:00 p.m. (EST). E-mail address: getinfo@haworthpressinc.com].

(C) 2002 by The Haworth Press, Inc. All rights reserved. 
no longer be accessed within a year of the online source's publication. The author suggests that librarians and scholars be aware of the risk digital publishing presents to future research. [Article copies available for a fee from The Haworth Document Delivery Service: 1-800-HAWORTH. E-mail address: <getinfo@haworthpressinc.com> Website: <http://www.HaworthPress.com> (C) 2002 by The Haworth Press, Inc. All rights reserved.]

KEYWORDS. Online legal research, digital publishing, source authority, legal scholarship

\section{INTRODUCTION}

\section{Reliability: Essential Attribute of Scholarship}

Scholars have engaged in the enterprise of scholarship for centuries, even millennia. The Oxford English Dictionary defines scholarship as the "attainment of scholars,"2 and as "the sphere of polite learning." 3 Other definitions present it as the "pursuit of knowledge,"4 and as the activity that brings "wisdom to the nations."5 For example, Decartes" Method 6 explains how knowledge is built on past knowledge that is clearly and distinctly perceived as true. ${ }^{7}$ Thus, more than the transitory process of study, the production of new knowledge and the continuing search for truth cannot be done, at least not in the Western tradition, without reference to past knowledge.

As scholarship promotes "the development, representation, and utilization of knowledge,"8 it obviously requires accretion and derivation, which enable later scholars to build on earlier results of scholarship. The scholarly development of Greek philosophy, for example, was possible because Aristotle, and his contemporaries, as well as all those who came later, had access to Plato's Republic, and they had access to the same text regardless of the edition used. Additionally, whenever Plato's Republic is cited today as a source in a footnote, scholars and lay persons assume that it is the same one they already read. Scholarship thus requires access to the product of earlier study. It also requires some assurance that what is accessed faithfully reproduces the original.

Irrespective of how variously it is defined from age to age and discipline to discipline, scholarship thus relies on "a base of expertise, a 'scholarly knowing' that needs to and can be identified, made public and evaluated." This accurate access (emphasizing both access and accuracy) to sources is defined here as reliability. ${ }^{10}$ Reliability, in this sense, ensures that both lay persons and other scholars might share the same product. ${ }^{11}$ Reliability, as one of the prerequisites of Western 
scholarship allows acknowledgement of the sources used in a scholarly product, ${ }^{12}$ and, by way of consequence, assurance of access to their faithful reproductions.

\section{Reliability: Essential Attribute of Legal Scholarship}

As the pursuit of legal knowledge, legal scholarship ${ }^{13}$ is no different from other disciplines. Legal scholarship bears the same essential attributes as any other type of scholarship, including reliability. In legal literature, the importance of reliability has assured access to and accuracy of the content is exemplified by the notorious footnoting culture within law review articles. ${ }^{14}$ As is commonly known, legal scholarship relies on the existence and reliability of accessible materials as the means of verification of the accuracy and validity of the ideas advanced within a legal text. There are thus at least two possibly overlapping features of scholarship that directly apply to the form and content of footnotes, all of which are impacted by the advent of digital publishing-the dual needs for access and accuracy, which, to repeat, is defined here as reliability.

\section{STATEMENT OF PURPOSE}

In addition to reliability defined as assured access and accuracy of the content, this paper discusses the impact on legal scholarship of digitization (which will include electronic publishing) in relation to the same requirement of reliability. While there is a vast array of legal and non-legal literature addressing the role of scholarship, its content, or its authorship, there is no single source discussing reliability-as used here-as an essential aspect of legal scholarship. ${ }^{15}$ This paper argues that reliability is an essential attribute of legal scholarship because, as is true of all scholarship, it requires accurate access to the products of earlier study. It further argues that digital publishing as defined here, ${ }^{16}$ at least potentially, may have a direct impact upon legal scholarship, and as shown below, there are reasons to worry. There are several reasons why digital publishing inherently places reliability at risk. First, self-publishing, much-celebrated ${ }^{17}$ but often unexamined, raises the risk that non-institutional sources may not have the stability over time to assure reliable access nor the internal regulation to assure that different versions are always so identified like different editions, translations, etc. Second, the electronic transmission inherent to digital publishing, as shown herein, raises technical risks to both access and accuracy. Third, because digital publishing is itself a technological innovation, it raises the problem inher- 
ent to all innovation-that of changing standards and formats, increasing the risk of future problems of access and perhaps of accuracy as well.18

\section{REVIEW OF RELATED LITERATURE}

\section{Legal Scholarship: Generalities}

Whether viewed narrowly as simply the work product of law professors in addition to their classroom duties, ${ }^{19}$ or more broadly as "that scholarship that seeks to inform and guide practitioners, legislators, other policymakers, and judges," 20 legal scholarship is merely a discipline specific form of scholarship. Thus, it requires the same degree of reliability, in terms of accurate access to any body of work, so that it, too, can serve as a source of "wisdom." Nevertheless, works on legal scholarship seem to ignore this aspect of the very nature of scholarship, instead focusing on the professional or social role ${ }^{21}$ of such scholarship, its content, ${ }^{22}$ or issues of authorship. ${ }^{23}$

For example, in 1998, Mary Beth Beazley and Linda H. Edwards produced a comprehensive bibliography of law review articles on legal scholarship, "The Process and the Product: A Bibliography of Scholarship about Legal Scholarship." ${ }^{24}$ Although it contains articles divided into five categories, none of these categories seem to focus on scholarship's reliability, as defined here as assurance that the public or later scholars have access to tamper-free content including its cited sources.

For example, Beazley and Edwards' first two categories focus on the needs of new members of academia. The very titles of the categories-"How and Why To Do Scholarship," and "The Broader Value of Scholarship"-purport to supply the rationale for the very idea of legal scholarship and its mechanics. There are twenty-seven articles mentioned under the first category and fifty-eight in the second. ${ }^{25}$ However, the "how" and "why" are not related to the broader significance of scholarship within the realm of human knowledge. Instead, as is the question of its value, they are devoted to its significance to the professional and social lives of these academics.

The next three categories examine what constitutes legal scholarship in terms of format (whether or not they are published in law reviews, which law reviews in particular with regard to the well-known hierarchy of law review prestige, and the procedures by which various reviews select articles for publication ${ }^{26}$ ), topicality, and authorship. The third category "Comments on Scholarship in General," contains 103 articles; the fourth category, "Comments on Emerging Forms of Scholar- 
ship," contains eighty-eight; and the final category, "Critiques of the Publication and Editorial Process" contains sixty articles. In sum, there is a great deal of material devoted to the professional significance of legal scholarship, but there is very little, if any, relating it to the enterprise of scholarship generally-or, more particularly, to its function and nature within the Western tradition. Since 1998, the same lack of attention to scholarship's overall nature, especially the central requirement of reliability, accurately characterizes the literature in this pervasively electronic age. Authors are more concerned about dissemination-in the sense of immediate, though not necessarily long-range, access to information ${ }^{27}$-than reliability, which means assuring accurate and continuing access to the same body of work.

\section{Legal Scholarship: Digital Publishing}

For the purpose of this article, digital publishing includes electronic publishing (defined herein as the distribution of information directly in electronic format ${ }^{28}$ ) as well as digitization (the conversion of paper materials into electronic format ${ }^{29}$ ). Although digitization is often viewed in terms of archiving and electronic publishing in terms of accessing information, both are electronic means of disseminating information. Generally, law review articles that discuss electronic publishing seem to ignore its threat to reliability, in terms of assuring accurate access to the same body of work. ${ }^{30}$

For example, Michael Geist, in "Changing the Face of Legal Scholarship," 31 noted that the "Internet is [ . . ] having a significant impact on the dissemination of legal scholarship." Indeed, alternative electronic dissemination of legal journals affects their accessibility as a "democratiser of [ . . ] knowledge," 32 but dissemination alone does not assure reliability. Geist simply values dissemination, the immediacy of accessibility to information, not necessarily to the exclusion of, but surely without regard for, reliability.

M. Ethan Katsh raised the issue of the Internet impact on legal scholarship in nuanced ways. ${ }^{33}$ First, he lauds digitization because "the World Wide Web provides opportunities for interactivity, for forms of argument that are hypertextual and non-linear, and for graphical representations that were often discouraged in print journals." 34

At the same time he does not seem alarmed by the fact that publishing on the Web places information in, as even he puts it, a "form where [many] facets of print works such as fixity, uniformity, and authenticity, would be questioned," 35 or that publishing on the Web fundamentally 
alters the idea that every available copy is the same as every other copy. ${ }^{36}$ Storage or preservation issues are not mentioned. Katsh's article seems to suggest that reliability, storage, and preservation issues are of little concern. Only unbounded access to the work seems to count. Katsh's current stance seems radically and mischievously inconsistent with the views expressed in his 1989 book, The Electronic Media and the Transformation of Law, where he seemed concerned that "law may . . . be hurt by a process of communication that is open to doubt, is changeable and is not always subject to easy verification." 37

James L. Hoover, Professor of Law at Columbia Law School, examines the electronic age and its impact on legal scholarship and legal libraries. In his view, law libraries would become more concept than place. Although he does not raise the issue of digitization's potential negative impact on scholarship's public accessibility, as defined here, he clearly understands the value of such reliable access.

His discussion of optical imaging, ${ }^{38}$ as a way of storing and preserving scholarly products through this new age, recognizes the importance of this role of the law library, by capturing the exact image, let alone its digitized content, in reproducible form. As an aside, law libraries, by their very nature, ensure continuous public accessibility to the works listed in their catalogs. It seems inescapable and certainly logical that law libraries will become one of, if not the only, important custodians of electronic collections, assumedly fulfilling the same demands of accessibility, storage, and preservation as they do today in print or microform collections. Thus, it is appropriate to question whether the literature in this field is overly concerned with promoting the advantages of instant electronic dissemination, to the disadvantage and possible exclusion of questions regarding whether stored information is safe from alteration and inaccuracy. This concern is magnified when one considers the immediate cost of greater dissemination-the risk to reliability created by the much ballyhooed advent of self-publication.

\section{WHAT IS DIGITAL PUBLISHING'S IMPACT ON LEGAL SCHOLARSHIP?}

\section{Digitization and Its Impact: General Aspects}

Whether through digital publishing or electronic archiving, legal scholarship is under siege. While electronic publishing may be viewed as electro-publishing in opposition to in-print publishing, and digitization 
as electro-archiving in-print collections, ${ }^{39}$ legal scholarship products can be found in both. Digital data repositories contain digital libraries, CD-ROMs, and digital form databases, including LEXIS/NEXIS and Westlaw. Virtually all digital sources are accessed via the Internet, which usually means through the World Wide Web. Amongst legal digital databases, LEXIS and Westlaw are the major players, as they contain electronic versions of law reviews-the major repositories of legal scholarship (although, it is important to note that other sources, such as treatises and monographs, and all older works except for case reporters, are conspicuously absent from this format). Thus, it becomes obvious that digital publishing, whether in its broader or narrower senses, poses responsibilities in the area of legal scholarship because it raises such issues as assured access and accuracy. Digital information, excepting image-type documents, "by its very nature, is open to manipulation, alteration, reformatting, and erasure, because those who create and use digital information usually love consideration for the current use and nature of the information." 40

With print versions, reliability, in the sense of assured access, and accuracy, is easily assured. Traditionally, libraries received the works of scholarship and ensured their accessibility, storage and preservation. In the legal world, apparently, common sense rules produced reliabilitycontinuous public accessibility, archiving, and accuracy-and they have been regularly published in The Bluebook. ${ }^{41}$

\section{Digitization and Its Impact: Concrete Examples}

The Bluebook is a repository of rules that enable users of law reviews to find, and thus access cited, and by definition extant, legal scholarship; it ensures that legal scholarship possesses the kind of reliability that legal scholars demand in the sense of consistent citation equals assured access, and accuracy. ${ }^{42}$ Its role becomes clear if we understand that "[a] uniform and common-sense citation system makes legal writing easier and helps readers to retrieve cited works with a minimum of fuss. In the computer age, free-form citation may also hamper legal research."43

Until the advent of LEXIS and Westlaw, The Bluebook did not contain any rules regarding electronic sources, ${ }^{44}$ because legal scholarship was unquestionably limited to in-print format. ${ }^{45}$ Nevertheless when it started including rules about sources on electronic format, the rules to those citations essentially discouraged their use. For example, the 16th edition of The Bluebook ${ }^{46}$ dissuaded citations to online sources 
"[b]ecause of the transient nature of many Internet sources." 47 The rule tacitly acknowledged the lack of reliability of Internet sources. Allowing such extraordinary citations effectively opened the door to the acceptance of unreliable sources-a door that remains open today.

The 17th edition of The Bluebook ${ }^{48}$ distinguishes between the rules of citations covering commercial electronic databases (such as LEXIS and Westlaw) and those covering the rest of the online sources (thus covering the rest of the legal digital databases). It allows citations to LEXIS, Westlaw, and Dialog, in "preference to the other [online] sources" 49 because of their "reliability and authoritativeness." 50 The Bluebook, while allowing for citation to "authoriatative" online resources, maintains ${ }^{51}$ the inhibiting tone of its previous rule of giving Internet citations only as "parallel citations using the explanatory phrase 'available at," "52 and to the extent possible, mentioning "the traditional source." 53 At least by implication, citations lacking a traditional source are anticipated when citation to the traditional source is not possible, leaving the door opened in the 16th edition ${ }^{54}$ still ajar. ${ }^{55}$ Even if the rule was initially intended to discourage the use of less reliable forms, one of its unintended consequences has been to encourage or accept citation to electronic media of suspect reliability.

For example, of the first twenty of 535 results to a query which searched the LEXIS/NEXIS Academic Universe ${ }^{56}$ for law review articles published within the last six months and that cited at least four documents published on the Web, ${ }^{57}$ twelve articles, or $60 \%$ of those first twenty, cited at least one online source which had become publicly inaccessible when accessed within a year from their publication, modification or last contact by a user. Those online sources, as shown in the Appendix, varied from federal and local governmental sites to selfpublished ones. By allowing for citations to purely digitally published sources, then, The Bluebook, if only in what appears today to be extraordinary circumstances, has offered encouragement, however unintended, to those who would abandon traditional assurances of reliability. Although the LEXIS and Westlaw legal databases have become more and more reliable in terms of comprehensive accessibility, ${ }^{58}$ and seem to have passed the threshold The Bluebook imposes, no one can say that they offer the same reliability and access as the print version. Users understand that what they access on LEXIS, for example, may be the same only for as long as Reed Elsevier, Mead Data Central' ${ }^{59}$ successor ${ }^{60}$-the company that gives us LEXIS-has access to it. For example, after libraries gave up subscriptions to in-print French legal documents such as the French Official Journal, relying on LEXIS, LEXIS 
lost or abandoned its subscription to such French documents in the summer of 1999. Or, as another example of the fragility of digital collections, in November 1999, at the request of the University of Denver, ${ }^{61}$ both LEXIS and Westlaw removed from their collections Wines' "The Critical Need for Law Reform to Regulate the Abusive Practices of Transnational Corporations: The Illustrative Case of Boise Cascade Corporation in Mexico's Costa Grande and Elsewhere."62 Thus, currently, the article is only available through libraries' in-print collections. Furthermore, LEXIS and WESTLAW coverage, as shown here, is constantly changing, even if its central role as a reliable electronic repository of case law seems-so far-unvarying.

\section{CONCLUSIONS}

Law review articles about digital publishing and legal scholarship seem to celebrate and emphasize the greater distribution and range of sources since the advent of the Internet without concern for the effects digital publishing may have on scholarship's reliability. However, seemingly by definition, digital publishing brings either constant alterations to the content of online sources (see the "last modified" mention for every online source) or a short lifespan for far too many of those sources. ${ }^{63}$

As mentioned before, attempting a random sample of URLs, ${ }^{64}$ twelve cited works cited in the first twenty articles of recent law journals were no longer available. ${ }^{65}$ If these authors were truly faithful to The Bluebook, and these failed citations are only supplementary, then these failures are not fatal to the enterprise of legal scholarship. (This ignores, however, the continuing threat that arises from the possibility of exceptional rules.) To the extent, however, that the directions of The Bluebook do not absolutely compel citations to some alternative in-print source, the advent of digitization or electronic publishing has, at the very least, introduced a higher degree of risk to the entire enterprise.

Then, the looming question concerns what digital publishing offers in terms of legal scholarship when more and more research is done online and more sources seems to be stored online. To the extent digital libraries are controlled by law schools, ${ }^{66}$ law school libraries, ${ }^{67}$ governmental organizations, ${ }^{68}$ non-governmental institutions, ${ }^{69}$ companies whose business is to perform or assist online research, ${ }^{70}$ and other similar institutions, ${ }^{71}$ the access, preservation, and storage issues, although inevitably affected by the agendas of those controlling entities, seem relatively secure. 
Without those guarantees and absent any regulation (public or private) of the reliability of digital publishing, in terms of assured access and accuracy, the Internet may offer very little other than a starting research point to legal scholarship. Scholars and librarians cannot forget that digital publishing may indeed be more like a window than a strongbox for research, offering greater transparency and access but also greater fragility because of its transient nature.

History reminds us that the Library of Alexandria was burnt to the ground and that too many Eastern European libraries have been destroyed in local wars. It would be unfortunate if, through the apparently benevolent means of novel technical innovation, public accessibility to legal scholarship was limited.

\section{NOTES}

1. The term "digital publishing" is used to embrace two more conventional concepts: digitization, often limited to mean the conversion of printed to electronic content, and electronic publishing which embraces and frequently emphasizes the creation, storage, and transmission of digitized content. See, Amiran, Eyal. Electronic Time and the Serials Revolution, The Yale Journal of Criticism 10.2 (1997): 445-454.

2. OED, Vol. XIV (2nd edition), at 630.

3. Id.

4. A. Cornelius Benjamin. "The Ethics of Scholarship: A Discussion of Problems That Arise in Its Application." Journal of Higher Education, Vol. 31, No. 9. (Dec., 1960): 471-480, at 472.

5. Howard Mumford Jones. "The Scholar and the World: Scholarship as Ritual, Contest, and Civil Independence." Journal of Higher Education, Vol. 50, No. 4. (Jul.-Aug., 1979): 429-438, at 438.

6. René Decartes. Discourse on Method and Related Writings (Penguin Classics).

7. W. H. Walsh. "Knowledge in Its Social Setting." Mind, New Series, Vol. 80, No. 319. (Jul., 1971): 321-336.

8. Michael Paulsen and Kenneth A. Feldman. "Toward a Reconceptualization of Scholarship: a Human Action System." Journal of Higher Education. Vol. 66, No. 6 (Nov.-Dec. 1995): 15-40, at 16.

9. Id.

10. I thus use the term "reliability" throughout this piece to include accurate access to sources that reproduce faithfully the original source.

11. The tragedy of the library of Alexandria was not a physical one, but a trauma to the very nature of scholarship, for it fatally interfered with the ability of scholars to engage in their enterprise, the very essence of which is access to the stored product of earlier ages. The Library of Alexandria, built in the ancient Egyptian metropolis by the Ptolemies, in the fourth century BC, functioned as the world's first university, a great library, and a publishing house. When it burned down, its 700,000 of listed and classified manuscripts were destroyed. See Jon Thiem. "The Great Library of Alexandria Burnt: Towards the History of a Symbol." Journal of the History of Ideas, Vol. 40, No. 4. (Oct.-Dec., 1979): 507-526. 
12. Benjamin. "The Ethics of Scholarship ...," supra, at 480. Michael Paulsen and Kenneth A. Feldman. "Toward a Reconceptualization . ..,", supra note. See also Anthony Grafton. "The Death of the Footnote (Report on an Exaggeration). The Wilson Quarterly. Vol. 21, No. 1 (Winter 1997): 72-78, at 73. ("The story of the footnote in fact began long before Ranke, or the 19th century, dawned. Even in the ancient world, when most historians saw their genre as one that depended on oral reports from participants in the events they described, some found it necessary to cite official documents, such as treaties. Josephus, the historian of the Jews, and Eusebius, the historian of the early Christian church, produced elaborate compilations of earlier sources.")

13. See Mary Beth Beazley and Linda H. Edwards. "The Process and the Product: A Bibliography of Scholarship About Legal Scholarship." Mercer Law Review. Vol. 49 (Spring, 1998): 741-70, for an extensive bibliography on legal scholarship arranged by four subject categories: (1) "How and Why To Do Scholarship," (2) "The Broader Value of Scholarship," (3) "Comments on Scholarship in General," (4) "the development of emerging forms of scholarship, including interdisciplinary scholarship, clinical scholarship, and empirical scholarship," and (5) a "critique of the publication process," including articles about the more recent explorations of the implications of electronic publishing.

14. See Philip M. Davis and Suzanne A. Cohen. "The Effect of the Web on Undergraduate Citation Behavior 1996-1999." Journal of the American Society for Information Science (2000) (to appear) ("In the world of academic scholarship, references form a link to original works, give credit to original ideas, and form a network of connections to related documents."). See also Grant H. Morris. "The Shortest Article in Law Review History: A Brief Response to Professor Jensen." 50 Journal of Legal Education (June, 2000): 310, the entire text of which is reproduced here:

Not so! [FN1].

[FN1] I write this footnote only because at least one footnote is, or at least should be, mandatory for a law review article. I note that although the title to my article is longer than Professor Jensen's, see Erik M. Jensen, The Shortest Article in Law Review History, 50 J.Legal Educ. 156 (2000), the text is shorter (by one word), and there are fewer footnotes (by one footnote). If I had so desired, I could have shortened the text by merely proclaiming, "Wrong!" However, I did not assert that my article was the shortest, only that Professor Jensen's was not.

(emphasis added). See also Erik M. Jensen, The Shortest Article in Law Review History, 50 Journal of Legal Education (2000): 156.

15. On reliable accessibility as a technical issue in the general context of electronic publishing, see Martin Kramer. "The Politics and Processes of Scholarship," Change, Vol. 40, No. 4 (July-August 1996): 61. ("Plainly, some of these issues are purely technical, and technicians are the right people to resolve them-issues such as assuring the integrity and permanence of a tamper-proof archival record and authoritatively documenting claims of first publication.")

16. See, supra, fn. 1.

17. See, e.g., Bernard, J. Hibbits. "The LHR Electronic Resource Page: Changing Our Minds: Legal History Meets the World Wide Web." Law and History Review. Vol. 17 (Summer, 1999): 385-87. Bernard, J. Hibbits. "Last Writes? Re-Assessing the Law in the Age of Cyberspace." New York University Law Review. Vol. 71 (June, 
1996): 615-88, and Hoover, James, L. "Legal Scholarship and the Electronic Revolution.” Law Library Journal. Vol. 83. (Fall, 1991): 643-651.

18. One can view all innovations in writing as technical developments which have, on occasion, raised the risk of reliability. Were it not for this risk, the Rosetta stone would not have resisted decoding so well, nor would we face the continuing problem of attempting to understand the writings of the Hittites, the Mayans, and others. We do not know whether future generations will view what we think of as the height of modernity as nothing more than another form of undecipherable hieroglyphics.

19. Marin Roger Scordato. "The Dualist Model of Legal Teaching and Scholarship.” American University Law Review. Vol. 40. (Fall, 1990): 367-417.

20. Harry T. Edwards. "Another 'Postscript' to 'The Growing Disjunction Between Legal Education and the Legal Profession.' "Washington Law Review Vol. 69 (July, 1994): 561-572, at 571.

21. Kozinski, Alex. "The Relevance of Legal Scholarship to the Judiciary and Community: Address Who Gives A Hoot About Legal Scholarship?" Houston Law Review. Vol. 37 (2000): 295-319.

22. Many articles have been written on evaluating scholarship. See, e.g., Edward L. Rubin. "On Beyond Truth: A theory for Evaluating Legal Scholarship." California Law Review. Vol. 80 (July, 1992): 889-963.

23. Paul W. Kahn. The Cultural Study of Law. Reconstructing Legal Scholarship. at 129. Chicago: The University of Chicago Press, 1999. (decrying "legal scholarship made by legal practitioners").

24. Mercer Law Review. Vol. 49 (Spring, 1980): 741-70.

25. Of course, this author admits that there is a margin of error in her count, but it does not seem significant to the outcome.

26. See, e.g., William C. Whitford. "The Need for and Exclusive Submission Policy for Law Review Articles." Wisconsin Law Review. (January/February, 1994): 231-33.

27. In this sense the literature seems thrilled-to a fault-at the prospects of self-publication (the ultimate in access of a sort) without considering the greater risk implicit to such institutionally free information regimes. See, e.g., Bernard, J. Hibbits. "The LHR Electronic Resource Page: Changing Our Minds: Legal History Meets the World Wide Web." Law and History Review. Vol. 17 (Summer, 1999): 385-87. Bernard, J. Hibbits. "Last Writes? Re-Assessing the Law in the Age of Cyberspace." New York University Law Review. Vol. 71 (June, 1996): 615-88.

28. Martin Kramer. "The Politics and Processes of Scholarship."(book reviews) Change. Vol. 28 no. 4 (July-August 1996): 61-63, 61.

[W]e can think of electronic publishing as occurring whenever a reader receives material to be read or examined from a computer, whether or not it has existed or will ever exist as print on paper. This broadest definition would, of course, include many kinds of materials of interest or concern to society as a whole but not especially of interest to scholars, such as an Internet edition of The New York Times or a piece of digital pornography. It would also include materials transmitted via computer merely out of convenience, such as a facsimile or scanned version of a paper document housed at a remote library.

29. These definitions owe their brief and concise nature to Kent McKeever, director of Arthur W. Diamond Library.

30. Of course, there are many other scholarly products concerned about the accurate accessibility to electronically published works. See Kramer. "The Politics and Pro- 
cesses of Scholarship," Change, Vol. 40, No. 4 (July-August 1996): 61. ("However much electronic publishing there is now, how much there will be in the future, and how we choose to define it, there has to be concern when the presentation and accessibility of scholarly products change so drastically.")

31. Law and Technology (September 21, 1998), accessed at http://lsprod.mtcibs. com/lawtech/archive/199803.htm on October 18, 2000, at 4:02 p.m.

32. Simon Schama. "People's history Digital archives are a huge step forward in the democratization of historical knowledge." The Guardian (Nov 13, 1999): 24.

33. "Law Reviews and the Migration to Cyberspace." Akron Law Review. Vol. 29 (Winter, 1996) 115-120.

34. Id. at 119.

35. Id.

36. Id. Bernard J. Hibbits, professor at the University of Pittsburgh School of Law, shares the same enthusiasm. See Bernard, J. Hibbits. "The LHR Electronic Resource Page: Changing Our Minds: Legal History Meets the World Wide Web." Law and History Review. Vol. 17 (Summer, 1999): 385-87, and Bernard, J. Hibbits. "Last Writes? Re-Assessing the Law in the Age of Cyberspace." New York University Law Review. Vol. 71 (June, 1996): 615-88.

37. In Ethan Katsh, The Electronic Media and the Transformation of Law, at 94.

38. Hoover, James, L. "Legal Scholarship and the Electronic Revolution." Law Library Journal. Vol. 83. (Fall, 1991): 643-651, 647.

39. Middleton, Michael. Library Digitisation Project Management. Availability: Web site: http://educate.lib.chalmers.se/IATUL/proceedcontents/chanpap/middleto.html, accessed on October 20, 2000, at 5:57 p.m. ("Digital libraries are defined in many ways. A common understanding is that they are data repositories that are being newly created in digital form in databases, on Web sites, or from file servers in a variety of combined text and image formats.")

40. Peter Mazikana. "The Challenges of Archiving Digital Information." International Information and Library Review. Vol. 29 (1997): 307-317, at 313.

41. The Bluebook. A Uniform System of Citation. Cambridge: The Harvard Law Review Association.

42. James W. Paulsen. "Book Review: An Uninformed System of Citation." Harvard Law Review. Vol. 105 (May, 1992): 1780-1794, at 1786-87.

43. Id. at 1793-94. I use "in-print" to include all other forms of tangible works.

44. Nazareth A. M. Pantaloni III. "Legal Databases, Legal Epistemology, and the legal Order." Law Library Journal. Vol. 86 (Fall, 1994): 679-706, at 695. (discussing the 13th edition of The Bluebook.)

45. Id. at $1786-87$.

46. The Bluebook. A Uniform System of Citation. Cambridge: The Harvard Law Review Association, 1996.

47. Id. Rule 17.3.3. at 124 .

48. The Bluebook. A Uniform System of Citation. Cambridge: The Harvard Law Review Association, 2000.

49. Id. Rule 18.1 at 130.

50. Id.

51. Rule 18.2.1 at 133.

52. Id.

53. Id. 
54. The Bluebook. A Uniform System of Citation. Cambridge: The Harvard Law Review Association, 1996: Rule 17.3.3. at 124.

Because of the transient nature of many Internet sources, citation to Internet sources is discouraged unless the materials are unavailable in printed form or are difficult to obtain in their original form. When citing to materials found on the Internet, provide the name of the author (if any), the title or top-level heading of the material being cited, and the Uniform Resource Locator (URL). The Uniform resource locator is the electronic address of the information and should be given in angled brackets. For electronic journals and publications, the actual date of publication should be given. Otherwise, provide the most recent modification date of the source preceded by the term "last modified" or the date of access preceded by the term "visited" of the modification date is unavailable $[\ldots]$.

55. The Bluebook. A Uniform System of Citation. Cambridge: The Harvard Law Review Association, 2000: Rule 18.2.1 at 132-33.

This rule requires the use and citation of traditional printed sources, except when the information is not available in a printed source, or if the traditional source is obscure or hard to find and when the citation to an Internet source will substantially improve access to the same information contained in the traditional source. In the latter case, to the extent possible, the traditional source should be used and cited. In such cases, the Internet source may be given as a parallel citation using the explanatory phrase "available at" no explanatory phrase should be included when the author accesses only the Internet source [ . . . ]. For material found exclusively on the Internet, such as on-line journals, the explanatory phrase "at" should be used. The principles of Internet citation (other than the requirement of citing source actually used or accessed by the author) are intended to be flexible guidelines applied in light of the nature of the information being cited, the state of the Internet as it develops over time, the standards or requirements applicable to the citing work, and the uses to which the citing work are to be put $[\ldots]$.

56. Electronic Presentation: Lexis-Nexis, a division of Reed-Elsevier Inc.

57. The query dated November 10, 2000 looked for law review articles published within the last six months and which contained references to more than one electronic source. Thus, the query was limited to articles that mentioned the term "www" at least four times: "www. w/25 www. and www. and www."

58. See, e.g., Nazareth A. M. Pantaloni III. "Legal Databases, Legal Epistemology, and the legal Order." supra.

59. See West Publishing Co. v. Mead Data Central, Inc. 799 F.2d 1219 (8th Cir. 1986).

60. In 1994 Reed Elsevier paid \$1.5 billion for Mead Data Central, parent of the Lexis-Nexis online legal information service. See John J. Oslund. "West Publishing looks at options, including sale; Eagan firm hires investment bankers to help find 'financial strength to succeed.' "Star Tribune (August 30, 1995): $1 \mathrm{D}$.

61. Peter Monaghan. "A Journal Article Is Expunged and its Authors Cry Foul." Chronicle of Higher Education. (December 8, 2000): 14.

62. Denver Journal of International Law and Policy. Vol. 26 (1998): 453-515.

63. For example, when attempting to access the Uniform Resource Locator (URL) for a source cited in note 256 of Christina N. Gifford's "The Sonny Bono Copyright Term Extension Act," Dennis S. Karjala's Challenge to Constitutionality ("last modi- 
fied Nov. 13, 1999") <http://www.public.asu.edu/dkarjala/constitutionality.html>, the result achieved is a "not found" error.

64. The search was limited to law review articles containing citations that included "www" in their URL.

65. See the Appendix.

66. See Hastings College of Law's digital library on Center for Gender and Refugee Studies at http://www.uchastings.edu/cgrs/.

67. See Bora Laskin Law Library's digital library on Women Human Rights' Resources at http://www.law-lib.utoronto.ca/Diana/.

68. See the Library of Congress' legislative information database at http://thomas. loc.gov/.

69. See the United Nations' digital library at http://www.un.org/.

70. See LEXIS at http://www.lexis.com/ and Westlaw at http://www.westlaw.com/.

71. See JSTOR, at http://www.jstor.org.

\section{BIBLIOGRAPHY}

Amiran, Eyal, Electronic Time and the Serials Revolution. The Yale Journal of Criticism 10.2 (1997): 445-454.

Benjamin, A. Cornelius. "The Ethics of Scholarship: A Discussion of Problems That Arise in Its Application." Journal of Higher Education, Vol. 31, No. 9. (Dec. 1960): 471-480.

The Bluebook. A Uniform System of Citation. Cambridge: The Harvard Law Review Association, 2000.

Davis, Philip M. and Suzanne A. Cohen. "The Effect of the Web on Undergraduate Citation Behavior 1996-1999." Journal of the American Society for Information Science (2000).

Decartes, Rene. Discourse on Method and Related Writings (Penguin Classics).

Faerber, Charles, N. "Book Versus Byte: The Prospects And Desirability of a Paperless Society." The John Marhall Journal of Computer \& Information Law Vol. 17 (Spring, 1999): 797-829.

Grafton, Anthony. "The Death of the Footnote (Report on an Exaggeration)." The Wilson Quarterly. Vol. 21, No. 1 (Winter 1997): 72-78.

Haigh, Richard. "What Shall I Wear to the Computer Revolution? Some Thoughts on Electronic Researching in Law." Law Library Journal. Vol. 89 (1997): 245-264.

Hibbits, Bernard, J. "The LHR Electronic Resource Page: Changing Our Minds: Legal History Meets the World Wide Web." Law and History Review. Vol. 17 (Summer, 1999): 385-87.

Hibbits, Bernard, J. "Last Writes? Re-Assessing the Law in the Age of Cyberspace." New York University Law Review. Vol. 71 (June, 1996): 615-88.

Hoover, James, L. "Legal Scholarship and the Electronic Revolution." Law Library Journal. Vol. 83. (Fall, 1991): 643-651.

Jensen, Erik M. The Shortest Article in Law Review History, 50 Journal of Legal Education (2000): 156.

Jones, Howard Mumford. "The Scholar and the World: Scholarship as Ritual, Contest, and Civil Independence." Journal of Higher Education, Vol. 50, No. 4. (Jul.-Aug., 1979): 429-438. 
Kozinski, Alex. "The Relevance of Legal Scholarship to the Judiciary and Community: Address Who Gives A Hoot About Legal Scholarship." Houston Law Review. Vol. 37 (2000): 295-319.

Kramer, Martin. "The Politics and Processes of Scholarship." (book reviews) Change. Vol. 28 no. 4 (July-August 1996): 61-63.

Mazikana, Peter. "The Challenges of Archiving Digital Information.” International Information and Library Review. Vol. 29 (1997): 307-317.

Martin, Peter, W. "How New Information Technologies Will Change the Way Law Professors Do and Distribute Scholarship." Law Library Journal. Vol. 83 (Fall, 1991): 633-41.

Middleton, Michael. Library Digitisation Project Management. Availability: Web site: http://educate.lib.chalmers.se/IATUL/proceedcontents/chanpap/middleto.html, accessed on October 20, 2000, at 5:57 p.m.

Morris, Grant H. "The Shortest Article in Law Review History: A Brief Response to Professor Jensen." 50 Journal of Legal Education (June, 2000): 310.

Pantaloni, Nazareth A. M. III. "Legal Databases, Legal Epistemology, and the Legal Order.” Law Library Journal. Vol. 86 (Fall, 1994): 679-706.

Paulsen, James W. "Book Review: An Uninformed System of Citation." Harvard Law Review. Vol. 105 (May, 1992): 1780-1794.

Paulsen, Michael and Kenneth A. Feldman. "Toward a Reconceptualization of Scholarship: A Human Action System." Journal of Higher Education. Vol. 66, No. 6 (Nov.-Dec. 1995): 15-40.

Rier, David, A. "The Future of Legal Scholarship and Scholarly Communication: Publication in the Age of Cyberspace." Akron Law Review. Vol. 30 (Winter, 1996): 183-213.

Rubin, Edward L. "On Beyond Truth: A Theory for Evaluating Legal Scholarship." California Law Review. Vol. 80 (July, 1992): 889-963.

Scordato, Marin Roger. "The Dualist Model Of Legal Teaching And Scholarship.” The American University Law Review. Vol. 40 (Fall, 1990): 367-417.

Stefancic, Jean \& Delgado, Richard. "Outsider Jurisprudence and the Electronic Revolution: Will Technology Help or Hinder the Cause of Law Reform." Ohio State Law Journal. Vol. 52 (Summer, 1991): 847-58.

Thiem, Jon. "The Great Library of Alexandria Burnt: Towards the History of a Symbol." Journal of the History of Ideas, Vol. 40, No. 4. (Oct.-Dec., 1979): 507-526.

Walsh, W. H. "Knowledge in Its Social Setting." Mind, New Series, Vol. 80, No. 319. (Jul., 1971): 321-336.

\section{APPENDIX}

1. Gostin, Lawrence O. and James G. Hodge, Jr. "The Public Health Improvement Process in Alaska: Toward a Model Public Health Law." Alaska Law Review. Vol. 17 (June, 2000): 77-125. (The Web page of Alaska Department of Environmental Conservation-Division of Air and Water Quality, <http://www.state.ak.us/local/akpages/ENV.CONSERV/dawq/dec <uscore>dawq.htm> accessible on Apr. 14, 2000, ${ }^{1}$ but not on November 10, 2000.) 
2. Silberlight, Adam. "WWW. How to Be a Master of Your Domain.com: A Look at the Assignment of Internet Domain Names under Federal Trademark Law, Federal Case Law and Beyond." Albany Law Journal of Science \& Technology. Vol. 10 (2000): 229-280. (The Web page of Network Solutions $<$ http://www.networksolutions.com/legal/disclaimer. html $>$ accessible on Aug. $1,2000,{ }^{2}$ but not on November 10, 2000.)

3. Faust, Susan M. "Baby Girl or Baby Boy? Now You Can Choose: A Look at New Biology and No Law." Albany Law Journal of Science \& Technology. Vol. 10 (2000): 281-303. (The Web page of Bryan S. Jick's Gender Selection-The Latest Techniques for Choosing the Sex of Your Child <http://www.parenthoodweb.com/articles/ phw839.htm> accessible on Feb. 25, 2000, ${ }^{3}$ but not on November 10, 2000.)

4. John S. Goldkamp, "The Drug Court Response: Issues and Implications for Justice Change.” Albany Law Review. Vol. 63 (2000): 923-961. (The Web pages of The Center for Court Innovation, a public/private partnership that works to develop innovative court programs at $<\mathrm{http}$ ://www. community courts. org/resource/homecci.htm> and of The plan of the Midtown Community Court, at <http://www.courtinnovation.org/demo01mcc. html $>$ both accessible on April 4, 2000, ${ }^{4}$ but not on November 10, 2000.)

5. Karen Swenson. "School Finance Reform Litigation: Why Are Some State Supreme Courts Activist and Others Restrained?" Albany Law Review. Vol. 63 (2000): 1147-1182. (The Web page of the U.S. Census Bureau's Census of Governments <http://www.census.gov/ ftp/pub/econ/ www/go0100.html> accessible on March 26, 2000, ${ }^{5}$ but not on the census cite on November 10, 2000.)

6. Michael West. "High Court Study: Arrested Development: An Analysis of the Oregon Supreme Court's Free Speech Jurisprudence in the Post-Linde Years.” Albany Law Review. Vol. 63 (2000): 1237-1295. (The Web page of Oregon Blue Book: Voting and Voter Registration <http://www.sos.state. or.us/BlueBook/1999\%202000/state/elections/elections 27.htm> accessible on Apr. 20, 2000, ${ }^{6}$ but not on November 10, 2000.)

7. Mark Smith, Janice Buckingham, Conni Gibson, and Jason Dubchak. "Recent Legislative and Regulatory Developments of Interest to Oil and Gas Lawyers Alberta Law Review." Vol 38 (June, 2000): 170-257. (The Web page of the Government of Alberta's Code of Practice for the Temporary Diversion of Water for Hydrostatic Testing of Pipelines, $<$ http://www.gov.ab.ca/qp/ ascii/codes/divers.tex> last modified in October, $1999,{ }^{7}$ and inaccessible on November 10, 2000.)\

8. Samuel M. Stricklin and Alexander P. Okuliar. "Characterization of Healthcare Receivables: Are Post-Petition Healthcare Receivables Subject to Pre-Petition Liens as 'Proceeds' or 'Rents' under the Bankruptcy Code, or are They Excluded as After-Acquired Property?" American Bankruptcy Institute Law Review. Vol. 8 (Spring, 2000): 47-76. (The Web page of the Department 
of Health and Human Services's National Health Expenditures Projections 1998-2000 <http://www.hcfa.gov/stats/NHE-Proj/ proj1998/hilites.htm>, last modified Jan. 10, 2000, ${ }^{8}$ and inaccessible on November 10, 2000.)

9. Lucien J. Dhooge. "The Wrong Way to Mandalay: The Massachusetts Selective Purchasing Act and the Constitution." American Business Law Journal. Vol. 37 (Spring, 2000): 387-484. (The Web page of Central Intelligence Agency's The World Factbook 3 (1997) <http://www.odci.gov/ cia/publications/ factbook/bm.html > accessible on November 3, 1998, ${ }^{9}$ but not on November 10, 2000.)

10. Barbara Crutchfield George and Kathleen A. Lacey and Jutta Birmele. "The 1998 OECD Convention: An Impetus for Worldwide Changes in Attitudes Toward Corruption in Business Transactions." American Business Law Journal. Vol. 37 (Spring, 2000): 485-525. (The Web page of the Convention on Combating Bribery of Foreign Public Officials in International Business Transactions, Dec. 17, 1997, 337 I . L . M. 8 $<$ http://www.oecd.org./daf/ cmis/bribery/20nov23.htm>, ${ }^{10}$ not accessible on November 10, 2000.)

11. George J. Siedel. "Commentary: Six Forces and the Legal Environment of Business: The Relative Value of Business Law among Business School Core Courses." American Business Law Journal. Vol. 37 (Summer, 2000): 717-742. (The Web page containing the French Law of May 19, 1998 on Liability for Defective Products <http://www.faccparisfrance. com/them/5leg120 .htm>, accessible on July 29, 1999, ${ }^{11}$ but not on November 10, 2000.)

12. Gary Eisenberg. "Foreign Corrupt Practices Act." American Criminal Law Review. Vol. 37 (Spring, 2000): 595-615. (The Web page of the U.S. Department of Justice's Foreign Corrupt Practices Act Review Procedure Releases <http://www.usdoj.gov/criinal/fraud/fcpa/r8501.html>, accessible on October 10, 1999, ${ }^{12}$ but not on November 10, 2000.)

\section{NOTES}

1. "The Public Health Improvement ...," note 143, at 125.

2. "WWW. How to Be a Master of Your Domain.com: . . ," note 93, at 280.

3. "Baby Girl or Baby Boy? ...," note 7, at 303.

4. "The Drug Court Response ..., ," note 6, at 961.

5. "School Finance Reform Litigation ...,", note 72, at 1182.

6. "High Court Study . ...," note 1, at 1295.

7. "Recent Legislative and Regulatory Developments . . ," note 71, at 257.

8. "Characterization of Healthcare . . ," note 1, at 76.

9. "The Wrong Way to Mandalay ..., ," note 39, at 484.

10. "The 1998 OECD Convention ...," note 1, at 525.

11. "Commentary: Six Forces and the Legal Environment . . ," note 7, at 742.

12. "Foreign Corrupt Practices Act." note 72, at 615. 